\title{
ANALISIS TINGKAT KEBUGARAN JASMANI SISWA PENDIDIKAN PONDOK PESANTREN DI KOTA BENGKULU
}

\author{
Abu Hasan Al Jamil \\ PENJAS FKIP UNIB, e-mail: abuhasanaljamil@gmail.com \\ Sugiyanto \\ Universitas Bengkulu \\ Tono Sugihartono \\ Universitas Bengkulu
}

\begin{abstract}
Abstrak
Penelitian ini bertujuan untuk mengetahui kondisi kebugaran jasmani siswa pendidikan pondok pesantren di Kota Bengkulu. Penelitian ini menggunakan metode penelitian desktiptif kualitatif. Dalam melakukan penelitian ini terdapat 10 populasi pondok pesantren di Kota Bengkulu, Lalu di ambil 5 sebagai sampel yaitu:Pondok Pesantren Al Mubaarak, Pondok Pesantren Harsalakum, Pondok Pesantren Pancasila, Pondok Pesantren Darussalam dan Pondok Pesantren Hidayatullah dengan jumlah subjek 128 siswa. Penelitian ini menggunakan teknik analisis data yaitu teknik tabulasi frekuensi. Hasil Penelitian membuktikan bahwa pembelajaran pendidikan jasmani mempengaruhi kondisi kebugaran jasmani. Berdasarkan analisis data dapat disimpulkan bahwa kondisi kebugaran jasmani siswa Pondok pesantren dengan hasil tes lari 2400 Meter dalam bentuk presentase sebagai berikut:Siswa dengan kebugaran jasmani baik sekali 0\%, siswa dengan kebugaran jasmani baik 23 orang atau 17,96\%, siswa dengan kebugaran jasmani sedang 73 orang atau 57,03\%, siswa dengan kebugaran jasmani yang kurang 28 orang atau 21,87\% dan Siswa dengan Kebugaran jasmani yang sangat kurang yaitu 4 orang atau 03,14\%. Jadi berdasarkan hasil penelitian bahwa kondisi kebugaran jasmani berdasarkan jenis kelamin siswa Pendidikan Pondok Pesantren di Kota Bengkulu yaitu untuk kelompok laki-laki 11,27 menit yaitu sedang, untuk kelompok perempuan waktu rata-rata 15,02 yaitu Sedang.
\end{abstract}

Kata kunci : Kebugaran, Siswa-Siswi Pondok Pesantren, Kota Bengkulu

\begin{abstract}
This study aims to determine the condition of physical fitness of students educational boarding school in the city of Bengkulu. This study uses descriptive qualitative research. In doing this research there are 10 populations boarding school in the city of Bengkulu, Then grab sample 5 as follows: Al Mubaarak Boarding Schools, Harsalakum Boarding Schools, Pancasila Boarding Schools, Darussalam Boarding Schools and Hidayatullah Boarding Schools by the number of subjects 128 students. This study uses data analysis techniques, namely frequency tabulation technique. Research proves that learning physical education influence the condition of physical fitness. Based on data analysis can be concluded that the condition of physical fitness of students PondokPesantren with the results of a test run 2400 meters in the form of a percentage as follows: Students with good physical fitness once 0\%, students with good physical fitness 23 people or 17.96\%, students with physical fitness were
\end{abstract}


73 people or $57.03 \%$, students with less physical fitness 28 people or $21.87 \%$ and students with physical Fitness very less that 4 people or 03.14\%. So based on the findings that the conditions of physical fitness by sex Boarding Schools Education students in the city of Bengkulu, namely for the group of men 11.27 minutes which was, for women the average time of 15.02 is Medium.

Keywords: Fitness, Students Boarding School, City of Bengkulu

\section{PENDAHULUAN}

Pendidikan Jasmani merupakan suatu proses mendidik tidak hanya menekankan pada pengembangan aspek jasmani (jasadiyah/Psikomotor), tetapi juga pada pengembangan aspek kognitif (Al Aqlu), sosial (Hablum minal alam), emosional (Al Ruhyah/Afektif), dan Kesehatan (Al Afiyah/Bugar). Pada tataran pelaksanaan pendidikan jasmani merupakan "media" atau alat untuk mencapai tujuantujuan seperti disebutkan diatas. Dampak pengembangan pada pendidikan nilai ini tidak hanya cukup berkembang pada lingkungan persekolahan umum, tetapi juga mesti bermanfaat di lingkungan pondok pesantren. Secara hakikat sangatlah ideal bila pengembangan spiritual keagamaan dapat bersanding sejajar dengan media pendidikan pengembangan jasmani, sehingga manusia paripurna yang memiliki kualitas spiritual baik, jasmani prima, pengetahuan tinggi akan menjadi sumber daya yang sangat berharga bagi pengembangan sumber daya manusia Indonesia. Pengembangan ini akan lebih penting bila dikaitkan dengan pengembangan misi dan tugas kekhalifahan manusia dimuka bumi.

\begin{tabular}{|c|c|c|}
\hline & \\
\hline \\
\hline \\
\hline & & \\
\hline \\
\hline & & \\
\hline & & \\
\hline \multicolumn{3}{|r|}{$\begin{array}{l}\text { menyelenggarakan } \\
\text { lagi terbatas pada } \\
\text { berkaitan dengan }\end{array}$} \\
\hline
\end{tabular}

para santri. Kebugaran jasmani dilingkungan pondok pesantren perlu dibina untuk tercapainya proses belajar-mengajar yang optimal, karena penulis meyakini bahwa siswa yang memiliki kebugaran jasmani yang baik maka tugas aktivitas yang dilaksanakan dapat menjadi baik pula. Selain itu dengan kondisi kebugaran siswa yang baik, siswa dapat mengembangkan keterampilan fisikal yang memungkinkan siswa berpartisipasi dalam berbagai aktivitas jasmani serta mampu mengembangkan kebugaran fisikal dan berfungsi normalnya system tubuh untuk hidup aktif pada lingkungannya. Berikut Hadist yang diungkapkan oleh Umar Bin Khatab, anjuran untuk berolahraga yang berbunyi: ajarilah anak-anak kalian berenang, memanah dan berkuda.

Kebugaran jasmani itu penting bagi siswa pondok pesantren karena Aktivitas siswa Pondok pesantren berbeda dengan Aktivitas siswa pada sekolah umumnya. Siswa Pondok pesantren harus membaca AlQur'an seharian dari siang,sore dan malam bahkan harus membiasakan diri untuk bangun tengah malam untuk melaksanakan shalat malam, belum lagi tugas mata pelajaran dikelas hingga menimbulkan kerja fisik yang lebih berat. bayangkan kalau fisik siswa pondok pesantren tidak dibina dengan baik maka, kondisi fisik para siswa pesantren itu dalam keadaan lemah dan tidak bisa mengerjakan/melaksanakan aktivitas yang lebih luas/lebih berat. Maka disitulah pentingnya pendidikan jasmani di pondok pesantren di maksimalkan/dioptimalkan demi tercapainya kebugaran jasmani Siswa Pondok Pesantren tersebut.Sehubungan dengan itu maka perlu pengkajian lebih 
mendalam tentang kebugaran jasmani para siswa di pondok pesantren dalam kondisi saat ini. Adapun tujuan manfaat bagi guru, kepala sekolah, tim penyusun kurikulum di pondok pesantren untuk lebih mengkonsentrasikan/ menambah presentase pembinaan fisik untuk menunjang kebugaran fisik di pondok pesantren saat ini.

Berdasarkan observasi dan survey awal yang dilakukan penulis bahwa Jumlah Pondok pesantren di kota Bengkulu ini cukup banyak yang jumlahnya kurang lebih 10 pondok pesantren. Selanjutnya diperlukan penelitian terkait dengan status kebugaran jasmani siswa pondok pesantren di Kota Bengkulu, Untuk mengetahui secara umum gambaran pembinaan fisik di pondok pesantren (ponpes) yang hasilnya sebagai bahan masukan dan pengembangan kurikulum di lingkungan pondok pesantren itu sendiri. Masalah penelitian ini dirumuskan yakni; Bagaimanakah kondisi kebugaran jasmani siswa pendidikan pondok Pesantren di Kota Bengkulu? Pondok Pesantren (Ponpes) Merupakan lembaga pendidikan sekolah yang tumbuh dan berkembang dari masyarakat, oleh masyarakat untuk masyarakat. Pusat segala kebijakan penyelenggaraan pendidikan bersumber dari kyai sebagai pimpinan ponpes. Ponpes mensyaratkan para santrinya berada di pondokan baik siang maupun malam, sehingga dalam pelaksanaan pendidikannya ponpes lebih bersifat informal. (Uhamisastra 2 :2003). Pada awal abad kedua puluhan, unsur baru berupa sistem pendidikan klasikal mulai memasuki pesantren. Sejalan dengan perkembangan dan perubahan bentuk pesantren, menteri Agama RI Mengeluarkan peraturan nomor 3 tahun 1979, yang mengklasifikasikan pondok pesantren sebagai berikut:Pondok pesantren tipe $A$, yaitu dimana para santri belajar dan bertempat tinggal di Asrama lingkungan pondok pesantren dengan pengajaran yang berlangsung tradisional (Wetonan dan Sorongan). Pondok Pesantren Tipe B, Yaitu yang menyelenggarakan pengajaran secara klasikal dan pengajaran oleh kiyai bersifat aplikasi, diberikan pada waktu-waktu tertentu. Santri tinggal di asrama lingkungan pondok pesantren. Pondok pesantren tipe $\mathrm{C}$, yaitu pondok pesantren hanya merupakan asrama sedangkan para santrinya belajar di luar ( di sekolah atau madrasah umum lainnya), kyai hanya mengawas dan sebagai pembina para santri tersebut. Pondok Pesantren Tipe $D$, yaitu yang menyelenggarakan sistem pondok pesantren dan sistem sekolah atau madrasah. (Mahpuddin Noor, Potret Dunia pesantren (Bandung:Humaniora, 2006),h.44.

Secara umum jelas bahwa tujuan pendidikan jasmani di sekolah adalah untuk mengembangkan tiga ranah yang ada dalam individu, yaitu psikomotor, kognitif dan afektif. Dalam beberapa literatur tujuan pendidikan jasmani tidak hanya mengembangkan tiga ranah tadi, Buncher dan Krotee dalam bayu insanistyo (2014) pendidikan jasmani mempunyai 4 tujuan pokok, yaitu :Mengembangkan kebugaran jasmani peserta didik, Mengembangkan keterampilan gerak (psikomotor), Mengembangkan kognitif, Kebugaran Jasmani berasal dari kata bugar yang berarti tubuh dalam kondisi sehat dan kuat. Soedjatmo Soesmowardoyo menyatakan bahwa kebugaran jasmani adalah kemampuan tubuh menyesuaikan fungsi alat tubuhnya atau kerja fisik dengan yang cukup efisien tanpa lelah secara berlebihan. Secara umum pengertian kebugaran jasmani adalah kemampuan seseorang untuk menjalankan pekerjaan sehari hari dengan ringan dan mudah tanpa merasakan kelelahan yang berarti dan masih mempunyai cadangan tenaga untuk melakukan kegiatan yang lain. (Richar D.S A: 2011)Kebugaran Jasmani adalah 
kemampuan tubuh seseorang untuk melakukan tugas pekerjaan sehari-hari tanpa menimbulkan kelelahan yang berarti. (Depdiknas 2002: 2) Untuk dapat mencapai kondisi kesegaran jasmani yang prima seseorang perlu melakukan latihan fisik yang melibatkan komponen kebugaran jasmani dengan metode latihan yang benar.

Kebugaran jasmani dapat dibedakan menjadi dua aspek atau komponen, antara lain: kebugaran yang berkaitan dengan keterampilan meliputi; kecepatan, power,keseimbangan, koordinasi, dan kecepatan reaksi. Sedangkan kebugaran jasmani yang berkaitan dengan kesehatan meliputi; daya tahan jantung dan paruparu(Kardiovaskuler), kekuatan otot \& daya tahan otot(Kebugaran Otot), fleksibilitas dan komposisi tubuh" (Nurhasan. 2001: 132133). Kebugaran jasmani dapat dibedakan menjadi dua komponen, antara lain: kebugaran yang berkaitan dengan keterampilan meliputi; kecepatan, power, keseimbangan, koordinasi, dan kecepatan reaksi. Sedangkan kebugaran jasmani yang berkaitan dengan kesehatan meliputi; daya tahan jantung dan paru-paru (Kardiovaskuler), kekuatan otot \& daya tahan otot (Kebugaran Otot), fleksibilitas dan komposisi tubuh. (Nurhasan 2001:132133). Komponen kebugaran jasmani berkaitan dengan keterampilan: Kekuatan otot/Power (Muscle strength) adalah kemampuan untuk mengerahkan kekuatan dengan maksimum dalam waktu yang minim. Angkat besi merupakan contoh penggunaan power. Kelincahan (Agility) adalah kemampuan untuk merubah dengan cepat dan tepat posisi tubuh terhadap ruang. Loncat indah, gulat, senam merupakan contoh aktivitas yang memerlukan kelincahan.Keseimbangan (Balance) adalah pemeliharaan keseimbangan pada saat statis atau bergerak hand stand, berjalan di atas balok keseimbangan adalah contoh keterampilan yang memerlukan keseimbangan. Koordinasi (Coordination) adalah kemampuan untuk secara bersama melakukan berbagai tugas secara mulus dan akurat (tepat).

Mengembalikan pukulan bola tenis, memukul bola base ball, adalah contoh keterampilan olahraga yang memerlukan koordinasi.Waktu reaksi (Reaction time) adalah lamanya waktu antara perangsang dan respon. Respon seorang terhadap pistol start atau reaksi seorang pemain tenis terhadap servis yang keras adalah contoh situasi yang memerlukan waktu reaksi yang pendek. Kecepatan gerak (Speed of movement) adalah kemampuan untuk melakukan suatu gerak dalam periode waktu yang singkat. Kecepatan sangat diperlukan bagi pelari jarak pendek atau juga bagi seorang pemain sepak bola. Komponen kebugaran jasmani yang berkaitan dengan kesehatan: kebugaran kardiovaskuler (Cardiovasculer endurance) : kemampuan jantung untuk memompa darah \& menyalurkan oksigen keseluruh tubuh. Contoh latihan yang diberikan jalan kaki, dII" Kebugaran otot : "kekuatan" (seberapa berat beban yang dapat diangkat dengan aman) maupun "daya-tahan" otot (Muscle endurance). (berapa kalikah dapat mengangkat beban atau berapa lama dapat menahan suatu objek tanpa merasa lelah). Kebugaran otot penting sekali bagi kebanyakan aktivitas dari kehidupan seharihari. Kelenturan (flexibility): kemampuan untuk menggerakan persendian secara bebas tanpa merasakan nyeri melalui suatu rentangan gerak yang luas. Latihan peregangan akan membantu meningkatkan kelenturan pada persendian. Komposisi tubuh (BodyComposition) : kelebihan lemak memberikan beban tambahan terhadap sendi dan meningkatkan resiko terserang berbagai macam penyakit. (TIM Menpora).

Sejumlah ahli kesehatan olahraga sependapat bahwa dari Komponenkomponen tersebut di atas, komponen daya 
tahan adalah komponen terpenting dalam menentukan kebugaran jasmani seseorang. Daya tahan adalah suatu kemampuan tubuh untuk bekerja dalam waktu lama tanpa mengalami kelelahan setelah menyelesaikan pekerjaan tersebut. Daya tahan umumnya diartikan sebagai ketahanan terhadap kelelahan dan kemampuan pemulihan segera setelah mengalami kelelahan. Daya tahan yang tinggi dapat mempertahankan penampilan dalam jangka waktu yang relatif lama secara terus menerus. (Depdiknas: 2002). Manfaat Latihan Kebugaran Jasmani sebagai berikut: Mencegah penyakit jantung,Mencegah dan mengatur penyakit diabetes, Menurunkan tekanan darah tinggi, Menambah kepintaran, Memberi banyak energi, Menurunkan gejala depresi ringan dan kegelisahan, Menurunkan resiko kanker tertentu,Melindungi dari osteoporosis,Meningkatkan citra diri dan rasa percaya diri \&Membuat awet muda. Sumber (Kemendikbud.2013:169-170). Ada beberapa faktor yang mempengaruhi kebugaran jasmani seseorang antara lain: Makanan yang cukup dan bergizi. Fungsi makanan di dalam tubuh adalah untuk mendapatkan tenaga, zat-zat pembangun sel tubuh, meningkatkan daya tahan tubuh, dan untuk kelancaran segala macam proses yang terjadi di dalam tubuh.

Fungsi-fungsi tersebut dapat terpenuhi bila makanan yang dikonsumsi cukup secara kuantitas untuk memperoleh energi, cukup nilai gizi dan kestabilan metabolisme dalam tubuh. Kebiasaan hidup sehat. Kebiasaan hidup yang teratur, sehat dan dikerjakan secara kontinu akan dapat memperngaruhi tingkat kebugaran jasmani seseorang. Kebiasaan tersebut meliputi makan, mandi yang teratur, cuci tangan sebelum dan sesudah makan, gosok gigi, kebiasaan hidup bersih dan lain-lain, termasuk juga menghindari kebiasaan merokok, minumminuman keras dan mengkonsumsi narkoba. Istirahat atau tidur yang cukup. Pada dasarnya setiap kegiatan fisik harus didahului dengan pemanasan, kegiatan inti, kemudian pendinginan. Dalam aktivitas sehari-hari istirahat sangat diperlukan untuk memulihkan tenaga. Istirahat dapat berupa kegiatan yang tidak mengeluarkan banyak energi seperti duduk, berbaring dan tidur. Latihan jasmani atau olahraga. Salah satu cara untuk meningkatkan kebugaran jasmani adalah melalui latihan jasmani atau berolahraga secara teratur dan terus menerus. (Sopan Fitriani. 2012:13-14).

\section{Bentuk-Bentuk Latihan Kebugaran} Jasmani : Aerobik. Aerobik merupakan bentuk latihan yang melibatkan jantung dan paru-paru untuk bekerja lebih keras serta meningkatkan konsumsi oksigen keseluruh oleh tubuh sekaligus meningkatkan metabolisme tubuh. (aktivitas fisik yang dilakukan dengan waktu yang cukup panjang).Contoh latihan : lari $2,4 \mathrm{Km}$, bersepeda, berenang 4000m dll. An Aerobik. An Aerobik merupakan bentuk latihan singkat/latihan jangka pendek, tidak memerlukan pemanfaatan oksigen/kondisi tanpa oksigen. (aktivitas fisik yang dilakukan dalam waktu yang singkat sehingga tidak ada dalam aktivitas itu menggunakan oksigen dari luar). Contoh latihan : lari sprint $100 \mathrm{M}$, sit up, push up, pull up dll. Hasil ditemukan bahwa orangcoba yang melakukan latihan jasmani memiliki skor signifikan lebih tinggi dalam hal ingatan, logika alasan dan waktu reaksi daripada orang coba yang tidak melakukan latihan jasmani sama sekali. Ini terjadi dilandaskan pada asumsi "meningkatnya aliran darah ke otak sebagai akibat latihan jasmani, membantu untuk berfikir secara lebih cerdas dan lebih baik. (Uhamisastra, dkk. 2013).

\section{METODE}

Berdasarkan permasalahan yang akan dibahas dalam penelitian ini, maka jenis penelitian ini penelitian Deskriptif yang bertujuan untuk melihat suatu apa adanya. Seperti yang dikemukakan oleh Iskandar 
(2010:61) menjelaskan bahwa penelitian deskriptif merupakan penelitian untuk memberi uraian mengenai fenomena atau gejala yang diteliti dengan mendeskripsikan yuridis formal tentang nilai variabel mandiri, baik satu variabel atau lebih (independent).Tempat Penelitian ini dilakukan di tiap-tiap Pondok Pesantren yang ada di Kota Bengkulu pada bulan Februari - Maret 2017. Populasi penelitian ini adalah 10 ponpes jumlah keseluruhan siswa pondok pesantren yang berjumlah 1825 siswa. Lalu diambil 5 sampel/5 ponpes. Pondok pesantren al mubaarak, harsallakum, pancasila, darussalam, hidayatullah. sampel merupakan perwakilan dari seluruh populasi yang ada, Perwakilan ini telah dianggap mewakili populasi yang ada.

Sampel yang dipilih peneliti yaitu Random Sampling sederhana (simple Random Sampling) penggunaan teknik ini sangat mudah dan hasilnya memiliki tingkat representatif yang tinggi yang mewakili populasinya. (Endang Widi Winarni: 102). Dari kelima ponpes tadi diambil 1 kelas karena tiap ponpes itu ternaya jumlah siswanya berbeda lalu pertimbangannya jumlah keseluruhan siswa yang di bawah 40 apalagi ada ponpes jumlah siswanya hanya 12 tidak kita gunakan mrnghindari homogenitas jumlah sampel. Teknik pengumpulan data menggunakan tes mengukur kebugaran jasmani berkenaan dengan daya tahan paru $\&$ jantung yaitu tes lari dari Cooper. Tes lari 2,4 Km (Metode Cooper/Aerobik).Penelitian ini adalah pe nelitian deskriptif yang bertujuan untuk menggambarkan bagaimana tingkat kebugar an jasmani siswa di pondok pesantrenBengkulu. Apakah tergolong sang at baik, baik, sedang, kurang, atau kurang sekali. Untuk dapat mengetahui tingkat kebu garan jasmani siswa di pondok pesantren kotaBengkulu, maka peneliti menggunakan i nstrumen lari jauh 2,4 Km. Pelaksanaan : Sikap awal rombongan peserta tes yang telah di catat namanya oleh petugas diberangkatkan dari belakang garis start. Gerakan siap peserta bersiap akan berlari.Gerakan Aba-aba "Ya" peserta mulai berlari sampai menempuh 2,4 $\mathrm{Km}$. Pencatatan hasilnya dicatat pada saat peserta telah masuk finish. Dalam satuan menit dan detik. evalusi : Untuk mengetahui klasifikasi kebugaran jasmaninya, waktu tes yang ditempuh dicocokkan dengan tabel Norma yang berlaku menurut kelompok umur dan jenis kelamin. Apabila tidak dapat menyelesaikan/menempuh jarak 2,4 $\mathrm{Km}$. Berarti tes dinyatakan gagal. Setelah semua data diperoleh dalam penelitian ini, data diolah dengan menggunakan statistik deskriprif (tabulasi frekuensi) dengan cara menghitung dalam bentuk persen untuk menentukan tingkat kebugaran jasmani siswa ponpes di kota Bengkulu, Dengan Rumus Sebagai Berikut: $P$ sama dengan $F$ per $\mathrm{N}$ kali $100 \%$. Keterangan $: \mathrm{P}=$ Presentase, $\mathrm{F}=$ Frekuensi, $\mathrm{N}=$ Jumlah Sampel, $100 \%=\quad$ Bilangan Konstanta/Bilangan Tetap.

\section{HASIL DAN PEMBAHASAN \\ Hasil Penelitian}

hasil penelitian dari 128 siswa Pondok Pesantren di kota Bengkulu yang menjadi sampel ternyata tidak terdapat siswa yang memikili kondisi kebugaran jasmani yang Sangat baik 0\%, Siswa yang memiliki Kebugaran Jasmani Baik yaitu 23 orang atau $17,96 \%$, Siswa yang memiliki kebugaran jasmani sedang berjumlah 73 orang atau 57,03\%, Siswa yang memiliki kategori kebugaran kurang berjumlah 28 orang atau $21,87 \%$ dan siswa yang memikili kategori kebugaran jasmani yang kurang sekali yaitu 4 orang atau $03,14 \%$.

\section{Pembahasan}

Faktor-faktor yang mempengaruhi kebugaran jasmani dilihat dari pola aktivitas siswa ponpes, faktor gizi, kurikululum pembelajaran PJOK /RPP dan Silabus PJOK, fasilitas sarana dan prasarana, tenaga 
pengajar/guru dan ekstrakurikuler semua telah terlaksana dengan baik hanya frekuensi pembelajaran yang dilaksanakan hanya $1 x$ dalam seminggu di tiap-tiap Pondok Pesantren Sehingga menyebabkan rata-rata kebugaran jasmani sedang karena dalam teori kebugaran bahwa untuk mencapai kebugaran jasmani yang prima harus melakukan aktivitas jasmani minimal $3 x$ dalam seminggu.

\section{PENUTUP}

\section{Simpulan}

Berdasarkan hasil penelitian dan pembahasan yang telah di uraikan pada Bab sebelumnya maka peneliti dapat mengambil kesimpulan sebagai berikut : Ditinjau dari pola aktivitas, kebutuhan gizi terpenuhi, sarana/fasilitas yang seadanya, guru yang berkualifikasi S-1 dan terdapat pembelajaran PJOK di ponpes sehingga berbanding lurus dengan hasil tes kebugaran jasmani di pondok pesantren. Peran mata pelajaran PJOK berdampak pada kebugaran jasmani siswa. Tanpa pembelajaran PJOK maka kondisi kebugaran jasmani siswa Ponpes dalam keadaan rendah. Secara umum Jika digabungkan kategori sedang keatas maka $57,03 \%+17,96 \%=74,99 \%$. Hasil secara terici status kebugaran jasmani siswa pondok pesantren sebagai berikut : kondisi kebugaran jasmani baik sekali $0 \%$, kondisi kebugaran baik yaitu 23 orang atau 17,56\%, kondisi kebugaran jasmani sedang 73 orang atau $57,03 \%$, kondisi kebugaran jasmani kurang 28 orang atau $21,87 \%$ dan kondisi kebugaran jasmani kurang sekali 4 orang atau $3,14 \%$. Jadi kategori kebugaran jasmani siswa pondok pesantren di Kota Bengkulu berdasarkan jenis kelamin sebagai berikut :Untuk kelompok laki-laki waktu rata-rata adalah 11,27 menit masuk kategori Sedang dan untuk kelompok perempuan waktu ratarata adalah 15,02 masuk kategori Sedang.

\section{Saran}

Berdasarkan dari hasil kesimpulan maka penulis menyarankan:

1. Perlunya penelitian Kebugaran Jasmani Lebih Lanjut.

2. Perlu nya penambahan sarana dan prasarana olahraga di tiap-tiap Ponpes,

3. Untuk ponpes yang belum memiliki guru PJOK semoga secepatnya mendapatkan guru PJOK baru.

4. Sekolah/ Ponpes harus lebih memperhatikan siswa/Santri dalam pembelajaran PJOK agar proses PJOK terlaksana dengan baik. Sehingga tercapainya tujuan PJOK Yaitu Kebugaran Jasmani.

\section{DAFTAR PUSTAKA.}

Depdiknas. (2002). Ketahuilah tingkat kesegaran jasmani anda. Jakarta: Pusa Pengembangan Kualitas Jasmani.

Iskandar. (2010). Metode Penelitian Pendidikan dan Sosial (Kualitatif dan Kuantitatif). Jambi: GP PRESS

Insanistyo, B \& Pujianto, D. (2014). Managemen Pendidikan Jasmani dan Olahraga. Bengkulu: Universitas Bengkulu Fakultas Keguruan dan Ilmu Pendidikan.

Nurhasan. (2001). Tes dan Pengukuran Dalam Pendidikan Jasmani: Prinsipprinsip dan penerapannya. Jakarta: Direktorat Jendral Olahraga.

Noor, Mahpuddin. (2006). Potret Dunia Pesantren. Bandung: Humaniora.

Richad, D.S. (2011) Berlatih Kebugaran Jasmani. Bogor: CV. CITRAUNGGUL LAKSANA.

Sopan Fitriani. (2012). Tingkat Kesegaran Jasmani dan Status Gizi Siswa Kelas VII SMP N 1 Bamtul Yogyakarta. 
KINESTETIK : Jurnal IImiah Pendidikan Jasmani,2 (1) 2018.

Yogyakarta: Universitas Negeri Yogyakarta (Skripsi).

Uhamisastra, dkk. (2003). Pengelolaan Model Pengajaran Pendidikan Jasmani di pondok pesantren. Bandung: Universitas Pendidikan Indonesia. Jurusan Pendidikan Olahraga. 